\title{
Long Island Vegetable Production: Research and Implementation Programs to Reduce Water Usage
}

\author{
Darlene Wilcox ${ }^{1}$ \\ Department of Fruit and Vegetable Science, Cornell University, Long Island Horticultural Research Laboratory, \\ Riverhead, NY 11901
}

The largest and most important source of groundwater in New York state is the underground aquifer beneath all of Long Island and the New York City boroughs of Brooklyn and Queens. It is the only source of drinking water for $>3$ million people and has been designated a sole-source aquifer by the Environmental Protection Agency (Hughes and Porter, 1983).

New York City's densely populated boroughs, which comprise the western most part of Long Island, originally depended totally on groundwater. However, excessive pumping in Brooklyn and areas in Queens resulted in salt water intrusion into the aquifer and its gradual abandonment in these areas. Brooklyn and much of Queens now depend on water imported from upstate surface water resources. Nassau County, the densely populated and industrialized portion of Long Island west of New York City, now has both serious water quality and quantity problems and looks to a future of water treatment, limited usage, and water importation from the island's east end (McIntyre, 1982).

In contrast to the growing water problems on western Long Island, Suffolk County, which encompasses the eastern two-thirds of Long Island, has a plentiful and pristine water supply. However, the public became aware of the potential for damage to the county's water supply in the mid-1970s, when the pesticide aldicarb (Temik) was used to control the Colorado potato beetle on $\approx 8100$ ha of potatoes grown on Long Island. Aldicarb, a highly soluble, toxic, and persistent material, was used at relatively highrates as a soil-applied insecticide from 1976 to 1979 . In 1979, aldicarb use was prohibited on Long Island when levels $>7 \mathrm{ppb}$, the state-recommended standard, were detected in private wells. Subsequently, $>2000$ wells were found to be contaminated. Nitrates and other agricultural chemicals have also been detected in the aquifer in Suffolk County (J. Baier, Suffolk County Health Dept., personal communication; Warner, 1985).

Currently, $\approx 4050$ ha of fresh-market vegetables and 2835 ha of potatoes are grown in Suffolk County-the most lucrative agricultural county in New York state. Because the porous sandy soils of Long Island have low water-holding capacities, both vegetable crop yield and quality depend greatly on irrigation. However, because the water supply has been plentiful and relatively inexpensive, little effort has been made to adopt technology that would ensure irrigation efficiency.

Although water is plentiful and its use is currently unregulated, future policies concerning agricultural water usage in Suffolk County are uncertain. In addition to concern about the effects of agricultural practices on water quality, there is concern about how the explosive residential and associated development in Suffolk County will contribute to the potential for contamination and depletion of the aquifer. Consequently, local agencies involved in water supply issues are

\footnotetext{
${ }^{1}$ Current address: Dept. of Fruit and Vegetable Science, Cornell Univ., Ithaca,
} NY 14853. encouraging conservation; regulation may not be far in the future. The recently established requirement by the New York State Dept. of Environmental Conservation for permits and flow meters for all new agricultural wells is viewed by some as a step toward future water-use restriction.

Programs directed at improving irrigation efficiency were initiated in 1982 by the U.S. Soil Conservation Service (SCS) and conducted in cooperation with Cornell Univ. and its Suffolk County Cooperative Extension. These efforts included 1) monitoring existing irrigation systems to evaluate both the systems' inherent efficiency and the way in which they are used, 2) improving systems through cost-sharing by the Agricultural Conservation Program, and 3) implementing irrigation scheduling programs for commercial sites.

\section{Irrigation systems evaluation}

Irrigation systems were evaluated and improvement or modification recommendations were made for specific sites on commercial vegetable and potato farms. System output, distribution uniformity, and soil moisture content before and after irrigation were evaluated. The results indicated that, of the various irrigation systems used on Long Island, movable pipe was the least efficient and effective, yet most commonly used, system. In contrast, big gun systems were most efficient at applying water in a timely and uniform manner but were used by few growers. Although each site was evaluated independently and recommendations for improving efficiency were made on a siteby-site basis, the overall pattern of irrigation practices appeared to be consistent among sites: irrigation water application was inefficient, nonuniform, and based on false assumptions. For example, growers commonly applied frequent light irrigations, rather than less frequent soil-saturating irrigations. Over-irrigation of sandy soils, in the hope of saturating these light soils, was also a common irrigation philosophy (Alan Connell, U.S. Dept. of Agriculture SCS, personal communication)

\section{Agricultural conservation program}

The second phase of SCS efforts to improve irrigation practices on Long Island involved funding from the Agricultural Conservation Program. This effort used an existing cost-sharing program for installing permanent improvements in irrigation systems to conserve water. Often, on Long Island, hydrants and underground mains were installed to replace the highly inefficient portable main-line pipes. The SCS provided technical assistance in installing trickle irrigation systems that also qualified under the cost-sharing program.

\section{Irrigation scheduling}

Recent SCS efforts to improve irrigation efficiency involved computer-scheduled irrigation at specific commercial sites. Computer- 
generated scheduling integrates environmental conditions, soil type, and water requirements for a particular crop to determine when and how much to irrigate. Program participation requires that growers monitor certain environmental data at their locations. Data reported to the SCS by the grower are used to generate a site-specific weekly irrigation schedule.

\section{Trickle irrigation research, Long Island}

Irrigation studies were conducted at the Cornell Univ. Long Island Horticultural Research Laboratory concurrently with the SCS water conservation program. Initial studies compared sprinkler and trickle irrigation methods for bell pepper (Capsicum annuum L) (VanDerwerken, 1986; VanDerwerken and Wilcox-Lee, 1988). These comparisons demonstrated the efficacy of trickle compared to sprinkler irrigation when trickle is used without the additional benefits of chemigation and fertigation. Integrated into these studies were cultural practices that are commonly used with trickle irrigation but not often used on Long Island. Black polyethylene mulch was compared to bare soil, and raised beds were compared to level ground. Irrigation was based on soil moisture levels, which were measured by mercury manometer tensiometers, to standardize soil conditions between irrigation systems. Irrigation was applied to return soil to field capacity when soil moisture reached a minimum of -0.025 or- $-0.075 \mathrm{MPa}$. Soil moisture in the nonirrigated plots was monitored with soil moisture blocks.

Pepper yield and quality were similar under the two irrigation systems when irrigation was based on soil moisture status. The advantages of reduced water use, labor requirements, and pumping costs inherent in trickle irrigation systems were demonstrated clearly by this project. In addition, using plastic mulch, even without irrigation, proved to be important in reducing water usage on the sandy soils of Long Island. Soil moisture levels of irrigated and nonirrigated plots under plastic mulch differed by only $0.03 \mathrm{MPa}$ until $\approx 9$ weeks after transplanting (Fig. 1). In contrast, in nonmulched, nonirrigated plots, soil moisture levels declined below those of irrigated or mulched plots by 6 weeks after transplanting. Soil moisture in nonirrigated, nonmulched plots increased between 6 and 7 weeks after planting due to natural precipitation received during that period. Because plastic mulch conserves soil moisture, it appears that reductions in total pepper yields due to soil moisture deficits in nonirrigated, mulched plots may not be evident until late in the season. There were no differences in pepper yields from irrigated, mulched plots and nonirrigated, mulched plots harvested through 16 Aug. (VanDerwerken and Wilcox-Lee, 1988). Thus, long-season crops grown on plastic could be irrigated later in the season than those grown in nonmulched plots.

Follow-up studies have demonstrated that, in fact, early yields in long-season crops grown on mulched, nonirrigated plots were not decreased compared with mulched, irrigated plots. Tomatoes (Lycopersicon esculentum Mill.) and peppers were grown on 1) black plastic mulch with no irrigation, 2) black plastic mulch with trickle irrigation when soil moisture reached a minimum of $-0.05 \mathrm{MPa}$, or 3) no mulch without irrigation. In both vegetables, early season yields (tomato harvested by 21 Aug. and pepper by 4 Aug.) in nonirrigated, mulched plots were similar to those in irrigated plots even though, by midseason, yields (tomato harvested by 9 Sept. and pepper by 25 Aug.) decreased in nonirrigated, mulched plots compared with irrigated plots (Table 1). Tomato yields had decreased by midseason in mulched, non irrigated plots. However, pepper yields were not reduced until late soil matric potential (MPa)

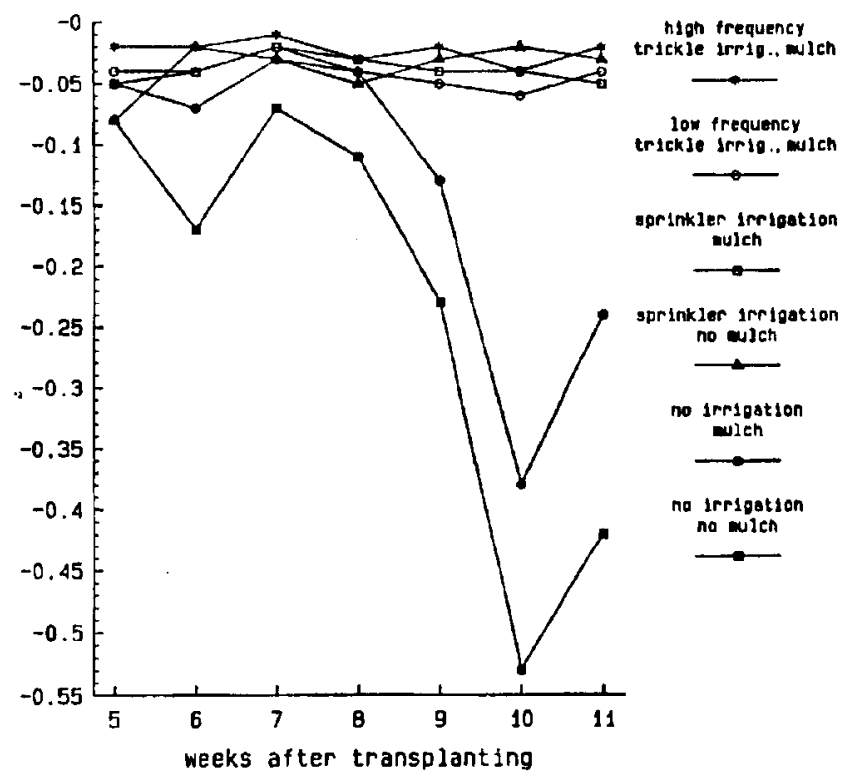

Fig. 1. Fluctuation of soil matric potential as influenced by irrigation and mulch [from VanDerwerken and Wilcox-Lee (1988), HortScience 26:295-298].

in the season (after 25 Aug.). Plastic mulch is an underused cultural practice on Long Island and, as demonstrated by these studies, has great potential for soil moisture conservation.

In summary, water quantity for agricultural use is not currently limited on Long Island. However, due to development pressure, the history of groundwater problems on western Long Island, and agricultural chemicals detected in the Suffolk County aquifer, water use may be restricted in the future. In addition, limiting agricultural water use may be an effective way to reduce further groundwater contamination due to agricultural chemicals leached in irrigation water. Research demonstration and implementation programs aimed at reducing agricultural water use are being conducted by the SCS and Cornell Univ. These programs involve evaluating existing systems and operation methods, recommending improvements of existing systems, implementing computer-generated irrigation schedules based on individual field sites and crops, and comparing conventional irrigation systems and cultural practices with water-conserving systems and practices.

\section{Literature Cited}

Hughes, H.B. and K.S. Porter. 1983. Land use and ground water quality in the Pine Barrens of Southampton. Water Resources Program, Center for Environmental Research, Cornell Univ., Ithaca, N.Y.

McIntyre, M. 1982. Long Island's endangered resource. Newsday Mag. 21 Nov. 1982. p. 12.

VanDerwerken, J.E. 1986. Effects of type and frequency of irrigation on the water relations, growth and yield of bell pepper (Capsicum annuum L.). MS Thesis, Cornell Univ., Ithaca, N.Y.

VanDerwerken, J.E. and D. Wilcox-Lee. 1988. Influence of plastic mulch and type and frequency of irrigation on growth and yield of bell pepper. HortScience 23:985-988.

Warner, M.E. 1985. An environmental risk index to evaluate pesticide programs in crop budgets. Cornell Univ., Dept. of Agricultural Economics Res. Publ. 85-11.

Table 1. Seasonal yield responses of 'Sunny' tomatoes and 'Big Bell' peppers to black plastic mulch and trickle or sprinkler irrigation applied at a soil matric potential of $0.05 \mathrm{MPa}$.

\begin{tabular}{|c|c|c|c|c|c|c|c|c|c|}
\hline \multirow{2}{*}{\multicolumn{2}{|c|}{ Treatment }} & \multicolumn{8}{|c|}{ Yields $\left(\mathrm{t} \cdot \mathrm{ha}^{-1}\right)^{2}$} \\
\hline & & \multicolumn{2}{|c|}{ Early season } & \multicolumn{2}{|c|}{ Midseason } & \multicolumn{2}{|c|}{ Late season } & \multicolumn{2}{|c|}{ Total } \\
\hline Mulch & $\overline{\text { Irrigation }}$ & Tomato & Pepper & Tomato & Pepper & Tomato & Pepper & Tomato & Pepper \\
\hline$\overline{\text { Yes }}$ & Yes & $8.4 \mathrm{a}$ & $21.5 \mathrm{a}$ & $62.5 \mathrm{a}$ & $24.6 \mathrm{a}$ & $20.4 \mathrm{a}$ & $29.8 \mathrm{a}$ & $91.3 \mathrm{a}$ & $75.9 \mathrm{a}$ \\
\hline Yes & No & $8.7 \mathrm{a}$ & $18.9 \mathrm{a}$ & $40.7 \mathrm{~b}$ & $25.6 \mathrm{a}$ & $16.7 \mathrm{~b}$ & $22.1 \mathrm{~b}$ & $66.1 \mathrm{~b}$ & $66.7 \mathrm{~b}$ \\
\hline No & No & $8.3 \mathrm{a}$ & $19.5 \mathrm{a}$ & $19.1 \mathrm{c}$ & $19.3 \mathrm{~b}$ & $16.3 \mathrm{~b}$ & $23.1 \mathrm{~b}$ & $43.6 \mathrm{c}$ & $61.8 \mathrm{~b}$ \\
\hline
\end{tabular}

${ }^{2}$ Mean separation within columns by Duncan's new multiple range test, $P=0.05$. Values are means of four replications with 20 (tomato) or 10 (pepper) plants per replication. 